GEFAD / GUJGEF41(2): 855-883(2021)

\title{
Araştırmaya Dayalı Öğrenme Yaklaşımı Modellerinden Rehberli Keşfetme Modelinin Görme Yetersizliği Olan Öğrencilerin Fene İlişkin Tutumlarına Etkisi ${ }^{* * *}$
}

\section{The Effect of Guided Discovery Model, one of the Inquiry- Based Learning Approaches, on The Attitudes of Students with Visual Impairment Towards The Science Course}

\author{
Tamer KARAKOÇ ${ }^{1}$, Ayşegül ATAMAN² \\ ${ }^{1}$ Gazi Üniversitesi, Gazi Eğitim Fakültesi, Özel Eğitim Bölümü. \\ tamerk@gazi.edu.tr \\ ${ }^{2}$ Lefke Avrupa Üniversitesi, Dr. Fazıl Küçük Eğitim Fakültesi, Özel Eğitim Bölümü. \\ ayataman@eul.edu.tr
}

Makalenin Geliş Tarihi: 10.03.2021

Yayına Kabul Tarihi: 21.04.2021

\section{$\ddot{O} Z$}

Araştırmanın genel amacı; ilköğretim 4. ve 5. sınıf Fen Bilimleri dersinde araştırmaya dayalı öğrenme yaklaşımı modellerinden rehberli keşfetme modeli ile geleneksel öğretim yaklaşımına göre işlenen dersin, görme yetersizliği olan öğrencilerin fen dersine ilişkin tutumları arasında anlamlı bir farklılık olup olmadığının belirlenmesidir. Araştırmada deneysel araştırma desenlerinden çok denekli desenlerin içinde yer alan yarı deneysel desen kullanılmıştır. Araştırmanın evreni Ankara ili Altındă̆ ilçesinde bulunan görme engelliler ilköğretim okulu, örneklemi ise deney grubunda $(N=20)$ ve kontrol grubunda bulunan $(N=19)$ toplam 39 öğrenciden oluşmaktadır. Araştırmada, öğrencilerin fene ilişkin tutumlarını ölçmek için Geban, Ertepınar, Yılmaz, Altın ve Şahbaz (1994) tarafindan hazırlanan "Fen Bilgisi Tutum Ölçeği" kullanılmıştır. Çalışmanın bulgularına göre; araştırmaya dayalı öğrenme yaklaşımının kullanıldi ̆̆ deney grubundaki ögrencilerin fene ilişkin tutumları, kontrol grubundaki öğrencilere göre anlaml düzeyde farklılık göstermistir. Deney grubundaki öğrencilerin cinsiyetlerine, sinıf düzeylerine ve görme düzeylerine fen dersine ilişkin tutumları arasında anlamlı bir farklılık bulunamamıştır. Sonuç olarak araştırmaya dayalı öğrenme yaklaşımının görme yetersizliği olan

\footnotetext{
* Alıntılama: Karakoç, T. ve Ataman, A. (2021). Araştırmaya dayalı öğrenme yaklaşımı modellerinden rehberli keşfetme modelinin görme yetersizliği olan öğrencilerin fene ilişkin tutumlarına etkisi. Gazi Üniversitesi Gazi Ĕ̌itim Fakültesi Dergisi, 41(2), 855-883.

** $\mathrm{Bu}$ makale birinci yazarın doktora tez araştırmasından türetilmiştir.
} 
öğrencilerin fen dersine ilişkin tutumlarını geliştirmede geleneksel öğretim yaklaşımına göre daha etkili olduğu söylenebilir.

Anahtar Sözcükler: Araştırmaya dayalı ögrenme yaklaşımı, Görme yetersizliği olan öğrenci, Rehberli keşfetme modeli, Tutum

\begin{abstract}
The aim of the research study is to understand whether there is significant difference between the Guided discovery model, one of the inquiry based learning approach models to the teaching science to 4th and 5th grade primary students and the contribution of a traditional teaching to the attitudes towards science lessons for the students with visual impairment. The quasi-experimental design, which is among the experimental research designs, which is among the multi-subject designs, was used in the study. The population of the study is a primary school for the visually impaired in Ankara, Altındag district, and the sample consists of 39 students in the experimental group $(N=20)$ and the control group $(N=19)$. According to the findings, the attitudes toward science lessons of the students with visual impairment in the experiment group in which the inquiry based approach was applied, were significantly different from those of the ones in the control group. No significant difference was found between the students in the experiment group in reference to their genders, class levels, and visual levels. In conclusion, it can be said that the inquiry based instruction approach has been more effective with students with visual impairment in developing their science attitudes when compared to the ones in traditional approaches.
\end{abstract}

Keywords: Inquiry-based learning, Students with visual impairment, Guided discovery model, Attitude

\title{
GíRiș
}

Fen eğitimi, özel eğitim ihtiyacı olan öğrenciler için önemli yere bir sahiptir. Özel eğitim ihtiyacı olan öğrencilerin dünyayı algılamaları, doğru kararlar vermeleri, problem çözme ve bilimsel tutum geliştirmelerinde, deneyim ve becerilerini arttırmalarında (Mastropieri ve Scruggs, 1995; Patton, 1995) fen eğitimi önemli katkılar sağlamaktadır.

Fen eğitiminin en önemli katkılarından biri, özel eğitime ihtiyacı olan öğrencilerin fen eğitimi ile çevrelerinde olup biten olgu, olay ve ilkeleri anlamaları sonucunda, doğru düşünme sistemi geliştirmelerine ve çevrelerine karşı doğru tepkiler vermelerine yardımcı olmaktır (Carin, Bass ve Contant, 2005; Güzel-Özmen ve Karakoç, 2020). Özel eğitime ihtiyacı olan öğrencilerin çevrelerini daha iyi anlayabilmeleri, çevresine bilimsel bir gözle bakabilmeleri ve iyi bir fen okuryazarı olabilmeleri için fen bilimleri 
dersinin önemi büyüktür (Atalay, 2019). Ancak, özel eğitime ihtiyacı olan öğrenciler Fen Bilimleri ile ilgili bilgi ve becerileri öğrenme konusunda çeşitli güçlükler yaşamaktadırlar (Yüksel ve Aslan, 2020). Fen Bilimleri derslerinde zorluk/güçlük yaşayan özel gereksinimi olan öğrenci gruplarından biri de görme yetersizliği olan öğrencilerdir. Öğrenilenlerin büyük bir bölümünün görme duyusu aracılığı ile kazanıldığı dikkate alındığında görme yetersizliği olan öğrencilerin; görme duyusunun kaybına bağlı olarak fen eğitimi sürecinde dezavantajlı duruma düşerek düşük performans sergileyebilirler (Karakoç, 2016). Bu performansı etkileyen birçok değişken bulunmakla birlikte değişkenlerden biri de ülkemizde uygulanmakta olan fen programlarıdir.

Ülkemizde görme yetersizliği olan öğrencilerin bulunduğu eğitim-öğretim ortamlarında uygulanan Fen Bilimleri programı olağan gelişim gösteren akranlarının bulunduğu eğitim ortamlarında bir farklılık göstermediği söz konusudur (Aslan ve Savaş, 2020). İlgili programda öğrencilerin bilişsel beceriler ve öğrenme özellikleri bakımından akranlarından daha dezavantajlı olmalarına karşın aynı fen programının uygulanması görme yetersizliği olan öğrencilerin ihtiyaçlarını göz ardı etmeyi sağlamaktadır (Kızılaslan ve Sözbilir, 2017; Sözbilir vd., 2017). Ayrıca Fen Bilimleri öğretmenlerinin de görme yetersizliği olan öğrencilerin öğrenme özelliklerine, ihtiyaçlarına uygun içeriği planlama ve uyarlama yapabilme becerileri yeterli olmadığı durumlarda öğrencilerin dersi anlamlandırma boyutunda sıkıntılar yaşayabilecekleri aşikârdır (Yazıcı, 2017). Görme yetersizliği olan öğrencilerin ihtiyaçları dikkate alınarak öğretim süreçlerinin düzenlemesi ve uygulanması; görme yetersizliği olan öğrencilerin daha etkili fen bilgi ve becerilerini öğrenmelerine kolaylık sağlayacaktır (Okçu, Yazıcı ve Sözbilir, 2016). Aksi takdirde Fen Bilimleri dersinin anlamlandırılmasında oluşabilecek sınırlıklar, derse yönelik olarak görme engelli öğrencilerin tutumlarını, motivasyonlarını ve öğrenme durumlarını olumsuz yönde etkileyebilecektir. Tutumlar ile fen bilimleri arasında önemli derece de bir bağlantı bulunmaktadır ve bilimsel olarak düşünüldüğünde tutumları olumlu olan öğrencilerin fen derslerine karşı olan tutumlarında da olumlu olarak gelişmektedir (Schibeci, 1983). 
Tutum, bireyin belirli bir konuya yönelik anlayışı ve duygularının bir göstergesi olarak bireyi olumlu ya da olumsuz bir davranış göstermeye sevk eden bir özellik olarak ifade edilmektedir (Kağıtçıbaşı, 1988). Bir derse veya konuya ilişkin tutum ise "dersi sevme ya da olumlu duyuşsal özellikler gösterme" veya tam tersi şekilde “dersi sevmeme ya da olumsuz duyuşsal özellikler gösterme" hali anlamına gelmektedir (Kahyaoğlu ve Yangın, 2007). Buna göre tutumlar davranışların eğilimini etkilediği sonucuna varılabilir. Öğrencilerin ilgili konu veya kavram hakkındaki ön bilgileri kadar söz konusu derse olan tutumları da büyük öneme sahiptir (Atalay, 2019).

Öğrencilerin sahip oldukları olumlu tutumlar akademik başarılarının artırmasına hizmet etmektedir. Bu öğrencilerin Fen Bilimleri derslerinde daha fazla çaba içerisinde oldukları belirtilmektedir (OECD, 2007). Fen bilimleri dersine ilişkin tutumların temelleri ilköğretimde atılmaya başlamakla birlikte ortaöğretimde de gelişmeye devam etmektedir (Saracaloğlu, Kesercioğlu, Gökler ve Serin, 2001). Öğrenciler Fen Bilimleri derslerini ne kadar çok severlerse, o dersi öğrenmeleri bununla beraber günlük yaşamla ilişkilendirmeleri o kadar kolay olabilir (Atalay, 2019). Dolayısıyla öğrencilere Fen Bilimleri derslerini sevdirebilmek için, somut materyallerin kullanımı, zengin aktivite, deney, gözlem, demostrasyon vb. gibi araştırma becerilerinin kullanıldı̆̆ 1 yaparak yaşayarak öğrenme etkinliklerinin düzenlenmesi gerekmektedir. Söz konusu etkinlikler öğrencilerin olumlu tutum oluşturmalarını destekleyecek niteliktedir. Bir diğer nokta ise öğrencinin merkeze alındığı ve öğrencilere aktif yaşantıların sunulduğu öğretimlerin yapılması gerekmektedir. Tüm bunlar öğrencilerin fen bilimleri dersine ilişkin olumlu tutumların geliştirilmesine hizmet etmektedir.

Alanyazında fen bilimleri dersine ilişkin tutumları inceleyen çeşitli araştırmalar (örn., Akpullukçu, 2011; Akpullukçu ve Günay, 2013; Belhan, 2012; Çakır vd., 2007; Doğruöz, 1998; Erden, 2007; Kaya ve Böyük, 2011; Lord ve Orkwiszewski, 2006; Marlow ve Ellen, 1999; Sakar, 2010; Tatar, 2006; Uyanık, 2017; Yılmaz ve Çavuş, 2021) söz konusudur. Bu araştırmalar incelendiğinde; Yılmaz ve Çavuş (2021) Probleme dayalı öğrenmenin ortaokul 5. sınıf Fen Bilimleri dersine ait "Işık ve Ses" ünitesinin öğrenilmesinde öğrencilerin akademik başarılarına ve fen bilimleri dersi 
tutumlarına etkisi olup olmadığını incelemiştir. Tatar (2006) öğrencilerin fene aynı şekilde düzeltilmeli dersin adı ilişkin tutumlarını geliştirme konusunda araştırmaya dayalı öğrenme yaklaşımının etkisini incelemiştir. Diğer bir araştırmada Akpullukçu ve Günay (2013) araştırmaya dayalı öğrenme ortamının öğrencilerin tutumlarına etkisini araştırmıştır. Belhan (2012) Bilim fen ve teknoloji kulübünün ilköğretim öğrencilerinin fen ve teknoloji okuryazarlık seviyelerine ve fene dersin adı doğru olmalı yönelik tutumlarına etkisinin olup olmadığını belirlemeyi amaçlamıştır. Çakır vd. (2007) ise çalışmalarında, ilköğretim öğrencilerinin Fen bilimleri dersine yönelik tutumlarını belirlemeyi amaçlamıştır. Uyanık (2017) ise diğer çalışmalara ek olarak; ilkokul 4. Sınıf öğrencilerinin fen bilimleri dersine yönelik tutumları ile akademik başarıları arasındaki ilişkiyi incelemiştir. Doğruöz (1998) fene dersin adı! yönelik tutumlar konusunda geleneksel öğretim yöntemi ile bilimsel süreç becerilerini kazandırmaya yönelik öğretim yöntemi arasındaki farkı belirlemeye incelemiştir. Kaya ve Böyük (2011) ilköğretim öğrencilerinin fene dersin adı! ve fen deneylerine yönelik tutumlarının belirlenmesini amaçlamışlardır. Koç ve Böyük (2012) ilköğretim 7. sınıf fen ve teknoloji dersi "Kuvvet ve Hareket" ünitesinde basit malzemelerle yapılan deneylerin öğrencilerin fene yönelik tutumlarına etkisini incelemişlerdir. Söz konusu araştırmalarda araştırmaya dayalı öğrenme yaklaşımının fene ilişkin tutumlar üzerinde etkili olduğu araştırmacılar tarafından ortaya konulmuştur (ör. Akpullukçu, 2011; Lord ve Orkwiszewski, 2006; Sakar, 2010; Tatar, 2006). Yapılan bu araştırmalar normal gelişim gösteren öğrenciler ile yürütülmüş̧ür. Ayrıca alanyazın taraması yapıldığında fen yönelik tutumların araştırıldığı çalışmaların daha çok II. ve III. kademedeler düzeyinde yoğunlaştığı görülmektedir (Uyanık, 2017). Görme yetersizliği olan öğrencilerle ve araştırmaya dayalı öğrenme yaklaşımı gibi modellerin kullanıldı̆̆ı fene ilişkin tutumları inceleyen sınırlı sayıda araştırmaya ulaşılmaktadır (ör. Atalay, 2019; Karakoç, 2016). Bu araştırmalarda Atalay (2019) görme yetersizliği olan öğrencilerin fene ilişkin öz yeterlilik, motivasyon ve tutumlarını belirlemeyi hedeflemiştir. Karakoç (2016) ise araştırmaya dayalı öğrenme ile geleneksel öğretim yaklaşımının görme yetersizliği olan öğrencilerin fene yönelik tutumlarını araştırmıştır. Gerçekleştirilen bu araştırmanın genel amacı; ilköğretim 4 ve 5. sınıf Fen Bilimleri dersinde araştırmaya 
dayalı öğrenme yaklaşımı ile geleneksel öğretim yaklaşımına göre işlenen dersin, görme yetersizliği olan öğrencilerin fene ilişkin tutumları arasında anlamlı bir farklılık olup olmadığının belirlenmesidir.

Araştırmanın görme yetersizliğinden etkilenmiş öğrencilerle çalışan öğretmenlere bilgi sağlaması bakımında önem arz edeceği ve görme yetersizliği olan öğrencilerle gerçekleştirilmesinden dolayı alanyazındaki bilgi birikimine katkı sunacağı düşünülmektedir.

\section{YÖNTEM}

\section{Araștırmanın Deseni}

$\mathrm{Bu}$ araştırmada, deneysel araştırma desenlerinden çok denekli desenlerin içinde yer alan yarı deneysel desen kullanılmıştır. Deneysel desenlerde temel amaç, değişkenler arasında oluşturulan neden sonuç ilişsisini test etmektir (Büyüköztürk, Çakmak, Akgün, Karadeniz ve Demirel, 2012). Deneysel araştırmalar, değişkenler arasındaki ilişkileri açıklamanın yanı sıra ilişkileri yorumlamaya ve bağımsız değişkenlere bağlı olarak sonucun nasıl etkilenebileceğini de ortaya çıkarmaktadır (Fraenkel ve Wallen, 2009; Karakaya, 2009). Yarı deneysel desenler ise denemeye katılan grup sayısı, kontrol önlemleri ve bağımsız değişken üzerinde yapılan gözlemlerin zaman ve sayısının dikkate alındığı bir yöntemdir (Campbell ve Stanley, 1996). Araştırmada, araştırmaya dayalı öğrenme yaklaşımı ile geleneksel öğretim yaklaşımına göre işlenen dersin, görme yetersizliği olan öğrencilerin fene ilişkin tutumları arasında anlamlı bir farklılık olup olmadığının belirlenmesi amaçlandığından yarı deneysel desenin kullanımı tercih edilmiştir.

\section{Evren ve Örneklem}

$\mathrm{Bu}$ araştırmanın evreni Ankara ili Altındağ ilçesinde bulunan Görme Engelliler İlköğretim Okulunda öğrenim gören 4. ve 5. sınıf öğrencileri arasından seçilen öğrencilerden oluşmaktadır. Araştırmanın örneklemi görme yetersizliği olan 39 öğrenciden oluşmaktadır. Öğrencilerin seçiminde ölçüt örnekleme yöntemi 
kullanılmıştır. Ölçüt örnekleme yöntemi, araştırmacı tarafından belirlenmiş bir dizi ölçütü karşılayan kişi, olay veya durumlara sahip katılımcı grubuyla çalışılmasını ifade etmektedir (Yıldırım ve Şimşek, 2016). Bu kapsamda; 4 veya 5. sınıfa devam etme, görme yetersizliğinin dışında herhangi bir engeli ya da yetersizliği olmama, kabartma (braille) okuma-yazma araçlarını kullanma, başat olarak dokunma ve işitme duyu kanalını kullanma ölçütleri ön koşul olarak belirlenmiştir. Ön koşulları sağlayan 39 görme engelli öğrenci araştırmaya dâhil edilmiştir. Ön koşullara sahip olan iki sınıf kontrol ve deney olmak üzere iki gruba ayrılmıştır. Özdeş olarak belirlenen gruplar yansız atama yoluyla eşit olarak ikiye bölünerek, yanlılık faktörü kontrol altına alınmıştır. Ayrıca okul yatılı ve gündüzlü öğrencilerden oluştuğu ve araştırmada öğrenci devamsızlığını önleyebilmek için; öğrencilerin öğretmenleri ile okulda yüz yüze görüşmeler yapılmıştır. Okula gündüzlü devam eden öğrencilerin aileleri ile telefonla görüşmelerde bulunulmuştur. Araştırma süresi boyunca okula gelen velilerle görüşmeler yapılmıştır. Bütün gerçekleştirilen görüşmelerde araştırmanın önemi ve öğrencilerin devam durumlarının araştırma açısından önemli olduğu vurgulanmıştır. Yapılan bu görüşmelerle denek kaybı tehdidi kontrol altına alınmaya çalışılmıştır.

Tablo 1. Örnekleme Ait Demografik Özellikler

\begin{tabular}{llccc}
\hline Değişken & Kategori & $\begin{array}{c}\text { Deney } \\
\text { grubu }\end{array}$ & $\begin{array}{c}\text { Kontrol } \\
\text { grubu }\end{array}$ & Toplam \\
\hline \multirow{2}{*}{ Cinsiyet } & Kiz & 6 & 5 & 11 \\
& Erkek & 14 & 14 & 28 \\
\hline \multirow{2}{*}{ Sınıf } & 4 & 10 & 10 & 20 \\
& 5 & 10 & 9 & 19 \\
\multirow{2}{*}{ Yaş } & 10 & 10 & 9 & 19 \\
\hline \multirow{2}{*}{ Okula devam şekli } & 11 & 10 & 10 & 20 \\
& Gündüzlü & 12 & 10 & 22 \\
\multirow{2}{*}{ Görme düzeyi } & Tatılı & 8 & 9 & 17 \\
\hline
\end{tabular}

Tablo 1 incelendiğinde, deney grubunda araştırmaya katılan öğrencilerin $(n=6) \mathrm{k} 1 \mathrm{z}$, $(n=14)$ erkek olduğu görülmektedir. Kontrol grubundaki öğrencilerin $(n=5)$ k1z, $(n=14)$ erkek olduğu belirlenmiştir. Deney grubundaki öğrencilerin $(n=10) 4$. sinıfta, $(n=10) 5$. sınıf düzeyinde öğrenim gördüğü tespit edilmiştir. Kontrol grubundaki öğrencilerin 
( $n=10)$ 4. sınıf düzeyinde, ( $n=9)$ 5. sınıf düzeyinde öğrenim gördüğü belirlenmiştir. Benzer şekilde deney grubundaki öğrencilerin $(n=10) 10$ yaşında, $(n=10) 11$ yaşında olduğu; kontrol grubundaki öğrencilerin $(n=9) 10$ yaşında, $(n=10) 11$ yaşında olduğu saptanmıştır. Deney grubunda araştırmaya katılan öğrencilerin $(n=12)$ gündüzlü, $(n=8)$ yatılı olduğu görülmektedir. Kontrol grubundaki öğrencilerin $(n=10)$ gündüzlü, $(n=9)$ yatılı olarak okula devam ettikleri belirlenmiştir. Öğrencilerin görme düzeylerine göre dağılımları incelendiğinde; deney grubundaki öğrencilerin $(n=14)$ total kör, $(n=6)$ az gören olduğu tespit edilmiştir. Kontrol grubundaki öğrencilerin $(n=12)$ total kör, $(n=7)$ görme yetersizliği olduğu saptanmıştır.

\section{Uygulama Süreci}

Araştırmacl

Araştırmac1; Gazi Üniversitesi Özel Eğitim Bölümünde öğretim elemanıdır. Araştırmacı Ankara ilinde bulunan Görme Engelliler Okullarında 1999 yılından beri son sınıf öğrencilerinin staj uygulamalarında danışmanlık yapmaktadır. 2000-2001 öğretim yılından beri ise hem Görme Engellilerin Eğitimi hem de Zihin Engellilerin Eğitimi Ana Bilim Dalında Fen Bilgisi ve Sosyal Bilgiler Öğretimi derslerini yürütmektedir. Araştırmacının konuya ilişkin bildirisi (Karakoç ve Şafak, 2003) ve kitap bölümü (Güzel-Özmen ve Karakoç, 2020) bulunmaktadır.

\section{Konulartn Belirlenmesi}

Araştırmada, işlenecek ders konularının belirlenebilmesi amacıyla araştırmacı tarafından görme engelliler okulunda çalışan dört Fen Bilimleri öğretmeni ile birer toplantı yapılmıştır. Bununla birlikte Millî Eğitim Bakanlığı (MEB) Fen Bilimleri Programı (MEB, 2013) gözden geçirilerek ve 4. ve 5. sınıflarda yer alan üniteler ve kazanımlar listelenmiştir. Daha sonra tüm araştırmacı ve öğretmenlerin katılımıyla bir toplantı yapılmış ve ortak kararla üç konu üzerinde uzlaşı sağlanmıştır. Bu konular: 1 . Sürtünme (kuvvet ve hareket, kuvvetin büyüklüğünün ölçülmesi), 2. Erozyon (gezegenimiz dünya, yer kabuğunun gizemi), 3. Çözünme (maddeyi tanıyalım, maddenin değişimi). 


\section{Ön Uygulama}

Fen bilimleri öğretmenleri, özel eğitim uzmanları ile yapılan görüşmeler sonucunda geleneksel öğretime dayalı öğretim sürecinde sorularla derse başlama, etkinlikle kavramları belirginleştirme, deney öncesi kavramları tanımlama ve kazandırma, kavramlara ilişkin örnekler verme, iki deneyin gerçekleştirilmesi, deney öncesi deneye ilişkin bilgilendirme, deneyin uygulanması, deney sonuçlarının tartışılması şeklinde planlanmıştır. Süreç öncesinde her sınıf düzeyinden dörder öğrenci olmak üzere toplam sekiz öğrenci ile ön uygulama gerçekleştirilmiştir. Ön uygulama sonuçları öğretimin doğru ve eksiksiz bir şekilde gerçekleştirildiğini ortaya koymuştur.

Araştırmaya dayalı öğrenme yaklaşımı modellerinden rehberli keşfetme modeline göre öğretim süreçleri şu şekilde belirlenmiştir: Soru oluşturma, Bilgi toplama, Bilgilerin kullanımı için rehberlik yapma, Deney yapma. Benzer şekilde konular için öğretimler planlandıktan sonra iki sınıf düzeyinde öğrenim gören sekiz öğrenci ile ön uygulama yapılmıştır. Ön uygulama ile öğretimin yanı sıra öğrencilerin oturma şekli, kullanacakları materyaller belirlenerek uygulama öncesinde tedarik edilmiştir.

Deney Süreci

Araştırma sürecinde uygulama öncesinde deney ve kontrol grupları oluşturulmuştur. Daha sonra sırasıyla ön testlerin uygulanması, iki farklı öğretim yöntemi ile öğretimin gerçekleştirilmesi, son testlerin uygulanması ve izleme testinin uygulanması işlemleri izlenmiştir.

Araştırmanın iç geçerliğinin sağlanabilmesi amacıyla araştırmanın bağımsız değişkenlerini uygulamadan önce, öğrencilerin devam ettiği okuldaki fen bilimleri, özel eğitim ve etüt öğretmenleri ile görüşmeler yapılmış ve bu öğretmenlerden araştırmanın uygulama süreci ve uygulama süreci tamamlandıktan sonra izleme verileri alınıncaya kadar (toplam dokuz hafta) ilgili konulara ilişkin herhangi bir çalışmada bulunmamaları istenmiştir.

Araştırmaya başlamadan önce görme yetersizliği olan öğrencilerin fene ilişkin tutumlarını ortaya çıkarmak amacıyla ön test verileri alınmıştır. Araştırmacı tarafından 
daha önceden kabartma (braille) yazı sistemine göre bastırılan tutum ölçeği görme yetersizliği olan öğrencilere dağıtılmıştır. Öğrencilerden yanıtlarını yine braille yazı ile ayrı bir sayfaya yazmaları istenmiştir. Bunun için öğrencilere kırk dakikalık bir zaman dilimi ayrılmıştır. Öğrencilerin yanıtları araştırmacı tarafından toplanmıştır.

Araştırmada, geleneksel öğretim yaklaşımına göre hazırlanan öğretim sürecinin uygulanması altı hafta ve 12 saat sürmüştür. Birinci ve ikinci haftada sürtünme, üçüncü ve dördüncü haftada erozyon, beşinci ve altıncı haftada çözünme konularının öğretimi geçekleştirilmiştir. Geleneksel öğretim yaklaşımına göre hazırlanan öğretim süreci uygulanırken ilk haftada, konuya ilişkin ön bilgiler üzerinde durulmuş, yoklamalar yapılarak kavramlara ulaşılmış, önceki bilgileri gözden geçirerek özetlemelerde bulunulmuş ve daha sonra konu kapsamında bir etkinlik yaparak ögrencilerin önceki bilgileri pekiştirilmiş̧ir. İkinci haftasında ise konuya ilişkin araştırmacı tarafından planlanan iki farklı deney yapılmıştır. Bu deneylerde araştırmacı, deney hakkında bilgi verdikten sonra deney düzeneğini oluşturmuş ve öğrencileri etrafına toplamıştır. Araştırmacı deneyi yaparken öğrencilere her aşamayı betimlemiş ve onların deney hakkında fikirlerini almıştır. Deney tamamlandıktan sonra sonuçlar üzerinde durulmuş ve işlevsel sonuçlar çıkarılarak dersi tamamlamıştır.

Araştırmada, araştırmaya dayalı öğrenme yaklaşımı modellerinden rehberli keşfetme modeline göre hazırlanan öğretim süreçlerinin uygulanması da altı hafta ve 12 saat sürmüştür. Birinci ve ikinci haftada sürtünme, üçüncü ve dördüncü haftada erozyon, beşinci ve altıncı haftada çözünme konularının öğretimi geçekleştirilmiştir. Araştırmaya dayalı öğrenme yaklaşımı modellerinden rehberli keşfetme modeline göre hazırlanan öğretim süreci uygulanırken ilk haftada, konunun ön bilgisine ilişkin sorular oluşturulmuş, daha sonra öğretimin yapıldığı ortamda şaşırtıcı etkinlik gerçekleştirilerek görme yetersizliği olan ögrencilere durum betimlenmiştir. Yapılan etkinlikle ilgili tartışma başlatılmış ve öğrencilerin fikirleri alınmıştır. Bu aşamadan sonra öğrencilere rehberlik yapılarak öğrencilerin soruları oluşturulmuştur. Araştırma görevleri verildikten sonra, öğrencilerin araştırma yapmaları istenmiştir. Daha sonra araştırma sonuçları gözden geçirilerek doğru bilgilerin oluşturulmasına rehberlik yapılmıştır. 
İkinci haftasında, öğrencilerle önce deneysel işlem becerileri belirginleştirildikten sonra öğrencilere tam rehberlik yapılarak deney planlatılmış ve deney uygulanmıştır. Deneyin sonuçları tartışıldıktan sonra öğrencilere rehberlik yapılmış ve işlevsel sonuçlar çıkarmalarına yardımcı olunmuştur. Dersin sonunda öğrencilere deneysel işlem becerileri belirginleştirme formları dağıtılmış ve aynı konuya ilişkin kendi deneylerini planlamaları istenmiştir. Bir sonraki derste, öğrencilerin ödevleri gözden geçirilmiş, planladıkları deney gerçekleştirilmiş ve sonuçları tartışılarak işlevsel sonuçlar çıkarmaları sağlanmıştır.

Deney süreci tamamlandıktan sonra görme yetersizliği olan öğrencilerin fene ilişsin tutumlarını belirleyebilmek için son test verileri ile birlikte dört hafta sonra izleme verileri alınmıştır. Son test ve izleme verileri alınırken araştırmacı tarafından daha önceden kabartma (braille) yazı sistemine göre bastırılan tutum ölçeği görme yetersizliği olan öğrencilere dağıtılmıştır. Öğrencilerden yanıtlarını yine braille yazı ile ayrı bir sayfaya yazmaları istenmiştir. Bunun için öğrencilere kırk dakikalık bir zaman dilimi ayrılmıştır. Öğrencilerin yanıtları araştırmacı tarafından toplanmıştır.

\section{Veri Toplama Araçları}

\section{Kişisel Bilgi Formu}

Kişisel Bilgi Formu, öğrencilerin demografik özellikleri hakkında bilgi almak amacıyla kullanılmıştır. Form, cinsiyet, sınıf düzeyi, yaş, okula devam şekli ve görme düzeyi değişkenlerini içermektedir. Formlar, öğrencilerin dosyalarından elde edilen bilgiler doğrultusunda araştırmacı tarafindan doldurulmuştur.

\section{Fen Bilgisi Dersi Tutum Ölçeği}

Görme yetersizliği olan öğrencilerin fene ilişkin tutumlarını belirlemek amacıyla Geban vd. (1994) tarafından geliştirilen ölçek kullanılmıştır. 15 maddeden oluşan ölçek beşli likert tipinde derecelendirilmektedir. Ölçekten en düşük 15 puan en yüksek ise 75 puan alınabilmektedir. Ölçeğin hesaplanan Cronbach alfa güvenirlik katsayısı 0,83'tür. Uçak'ın (2006) çalışmasında ise ölçeğin güvenirlik katsayısı 0,72 olarak rapor edilmiştir. $\mathrm{Bu}$ araştırmada ise ölçeğin güvenirliği ön testte 0,86 ; son testte 0,87 ve 
kalıcılık testinde 0,90 şeklinde hesaplanmıştır. Bu doğrultuda araştırma kapsamında öğrencilerin tutum ölçeğine vermiş oldukları cevapların güvenilir olduğu tespit edilmiştir.

\section{Uygulama Güvenirliği}

Araştırmada geleneksel öğretim yaklaşımına ve araştırmaya dayalı öğrenme yaklaşımı modellerinden rehberli keşfetme modeline göre planlanan derslerin, plana göre uygulanıp uygulanmadığını kontrol altına almak için öğretim oturumlarından uygulama güvenirliği verisi alınmıştır. Bunun için her iki bağımsız değişkenin uygulama oturumlarının \%30'u yansız atama yoluyla belirlenmiştir. Belirlenen oturumlara ait video kayıtları, Özel Eğitim Bölümü Görme Engelliler Eğitimi alanında çalışan bir öğretim üyesi ve yine aynı bölümde doktora yapan bir araştırmacı olmak üzere iki farklı araştırmacı tarafından izlenerek kodlanmıştır. Kodlanan veriler "Gözlenen Uygulamacı Davranışı/Planlanan Uygulamacı Davranışı x 100” formülü kullanılarak araştırmanın uygulama güvenirliği hesaplaması yapılmıştır (Tekin-İftar ve Kırcaali-İftar, 2006). Geleneksel öğretimin uygulama güvenirliği \%99,2 araştırmaya dayalı öğrenme yaklaşımı modellerinden rehberli keşfetme modeli uygulama güvenirliği $\% 98,8$ olarak tespit edilmiştir.

\section{Etik Kurallara Uygunluk}

Araştırmanın tamamında etik kurallar dikkate alınmıştır. Verilerin elde edilmesinde katılımcılara gerekli bilgilendirmeler yapılmış ve katılım tamamen gönüllülük ilkesi ile gerçekleştirilmiştir. Araştırmada yararlanılan kaynaklara bilimsel atıf kurallarına uygun olarak atıf yapılmış ve bu kaynaklar ilgili bölümde eksiksiz olarak verilmiştir. Hakkari Üniversitesi Etik Komisyonu'nun 25.02.2021 tarihli ve 2021/17 sayıl1 toplantı kararı ile araştırmanın etik açıdan uygun olduğuna karar verilmiştir. Etik kurul onayına ilişkin belge Ek 1'de sunulmuştur.

\section{Verilerin Analizi}

Verilerin analizinde betimsel istatistikler ile birlikte alt problemler doğrultusunda istatistiki hesaplamalar gerçekleştirilmiştir. Karşılaştırmalarda Mann Whitney U testi, 
Friedman testi ve Wilcoxon işaretler testi hesaplanmıştır. Araştırmada istatistiki testlerin anlamlılık düzeylerinin belirlenmesinde $\mathrm{p}$ olasılık değeri 0,05 olarak kabul edilmiştir. Sonuçlar tablolaştırılarak yorumlanmıştır.

\section{BULGULAR}

Öğrencilerin uygulama öncesinde, sonrasında ve kalıcılık çalışmasında fene ilişkin tutum düzeyleri belirlenmiştir. Bu doğrultuda hesaplanan betimsel istatistikler Tablo 2'de gösterilmiştir.

Tablo 2. Öğrencilerin Ön Test, Son Test ve Kalıc1lık Testi Puanlarının Betimsel İstatistikleri

\begin{tabular}{lllcccc}
\hline Grup & $\begin{array}{l}\text { Uygulama } \\
\text { zaman1 }\end{array}$ & N & Minimum & Maksimum & $\bar{X}$ & SS \\
\hline Kontrol & Ön test & 19 & 30,00 & 71,00 & 45,32 & 11,72 \\
grubu & Son test & 19 & 28,00 & 72,00 & 57,26 & 12,35 \\
& Kalıcılık testi & 19 & 22,00 & 68,00 & 53,53 & 13,54 \\
\hline Deney & Ön test & 20 & 21,00 & 69,00 & 50,60 & 14,91 \\
grubu & Son test & 20 & 56,00 & 75,00 & 67,00 & 6,03 \\
& Kalıcılık testi & 20 & 54,00 & 75,00 & 67,10 & 5,97 \\
\hline
\end{tabular}

Tablo 2 incelendiğinde, öğrencilerin tutum puan ortalamalarının testler ve gruplar bazında bazı değişiklikler gösterdiği görülmektedir.

Öğrencilerin tutum ölçeği ön, son ve kalıcılık testinden almış oldukları puanların anlamlı bir farklılık gösterip göstermediğinin tespit edilmesi amacıyla hesaplanan betimsel istatistikler ve Mann Whitney U testi sonuçları Tablo 3’te gösterilmiştir. 
Tablo 3. Öğrencilerin Ön, Son ve Kalıcılık Test Puanlarına İlişkin Hesaplanan Mann Whitney U Testi Sonuçları

\begin{tabular}{lccccccc}
\hline Ölçek/test & Gruplar & $\mathrm{N}$ & $\begin{array}{c}\text { Sira } \\
\overline{\mathrm{X}}\end{array}$ & $\begin{array}{c}\text { Sira } \\
\text { Toplamı }\end{array}$ & $\mathrm{U}$ & $\mathrm{z}$ & $\mathrm{p}$ \\
\hline $\begin{array}{l}\text { Fen Bilimleri } \\
\text { dersine yönelik } \\
\text { tutum-ön test }\end{array}$ & Deney & 20 & 26,98 & 539,50 & & & \\
\hline $\begin{array}{l}\text { Fen Bilimleri } \\
\text { dersine yönelik } \\
\text { tutum- son testi }\end{array}$ & Deney & 20 & 25,15 & 503,000 & & & \\
\hline $\begin{array}{l}\text { Fen Bilimleri } \\
\text { dersine yönelik }\end{array}$ & Deney & 20 & 26,98 & 539,50 & & & \\
$\begin{array}{l}\text { tutum- kalıcilık } \\
\text { testi }\end{array}$ & Kontrol & 19 & 12,66 & 240,50 & 50,500 & 3,925 & 0,000 \\
\hline
\end{tabular}

Tablo 3 incelendiğinde, uygulama öncesinde deney ve kontrol grubundaki öğrencilerin fene ilişkin tutum puanlarının anlamlı bir farklılık gösterdiği belirlenmiştir ( $\mathrm{z}=50,500$; $\mathrm{p}<0,05)$. Sira ortalama ve toplam puanlar incelendiğinde, deney grubundaki öğrencilerin çalışma öncesinde fene ilişkin tutumlarının kontrol grubundaki öğrencilere göre daha yüksek olduğu tespit edilmiştir. Öğrencilerin uygulama sonrasında fene ilişkin tutum ölçeğinden almış oldukları puanların da anlamlı bir farklılık gösterdiği tespit edilmiştir $(\mathrm{z}=2,900 ; \mathrm{p}<0,05)$. Sira ortalama ve toplam puanları incelendiğinde, deney grubundaki öğrencilerin kontrol grubundaki öğrencilere göre fene ilişkin tutum puanlarının daha yüksek olduğu saptanmıştır. Araştırma öncesinde kontrol grubundaki öğrencilerin tutum ölçeği ön test ortalama puanları $(\overline{\mathrm{X}}=45,32 \pm 11,72)$ ile son test puan ortalamaları $(\overline{\mathrm{X}}=57,26 \pm 12,35)$ arasında $11,94^{\prime}$ 'lük bir puan artışı olduğu belirlenmiştir. Deney grubundaki öğrencilerin tutum ölçeği ön testine vermiş oldukları cevapların ortalaması $(\overline{\mathrm{X}}=50,60 \pm 14,91)$ ile son testine vermiş oldukların cevapların ortalaması $(\overline{\mathrm{X}}=67,00 \pm 6,03)$ arasında ise 17,60 puanlık bir artış olduğu belirlenmiştir. Öğrencilerin puanları arasındaki bu artışı anlamlı bir farklılık göstermediği tespit edilmiştir ( $\mathrm{z}=0,535$; $\mathrm{p}>0,05)$. Başka bir anlatımla deney ve kontrol grubundaki öğrencilerin tutum puanlarındaki artışın benzerlik gösterdiği saptanmıştır.

Benzer şekilde deney ve kontrol grubundaki öğrencilerin tutum ölçeğinin kalıc1lık uygulamasından almış oldukları ortalama puanların anlamlı bir farklılık gösterdiği 
belirlenmiştir $(z=3,925 ; p<0,05)$. Sıra ortalama ve toplam puanlar incelendiğinde, deney grubundaki öğrencilerin kontrol grubundaki öğrencilere göre fene ilişkin kalıcılık tutum puanlarının daha yüksek olduğu tespit edilmiştir. Başka bir ifade ile deney grubundaki öğrencilerin fene ilişkin tutumları, kontrol grubundaki öğrencilerden daha olumludur.

Öğrencilerin gruplar bazında ön test, son test ve kalıcılık test puanlarının anlamlı bir farklılık gösterip göstermediğinin belirlenmesi amacıyla hesaplanan Friedman Testi sonuçları Tablo 4'te gösterilmiştir.

Tablo 4. Öğrencilerin Tutum Ölçeği Ön Test, Son Test ve Kalıcılık Testi Puanlarına İlişkin Hesaplanan Friedman Testi Sonuçları

\begin{tabular}{lllccc}
\hline Ölçek/ grup & $\begin{array}{l}\text { Uygulama } \\
\text { zamanı }\end{array}$ & $\mathrm{N}$ & Sıra $\overline{\mathrm{X}}$ & \multirow{2}{*}{$\mathrm{X}^{2}$} & $\mathrm{p}$ \\
\hline Fen Bilimleri dersine & Ön test & 20 & 1,25 & & \\
yönelik tutum-deney & Son test & 20 & 2,48 & 17,498 & 0,000 \\
grubu & Kalıcılık testi & 20 & 2,25 & & \\
\hline Fen Bilimleri dersine & Ön test & 19 & 1,50 & & \\
yönelik tutum-kontrol & Son test & 19 & 2,55 & 10,892 & 0,004 \\
grubu & Kalıcılık testi & 19 & 1,95 & & \\
\hline
\end{tabular}

Tablo 4'teki bilgiler incelendiğinde, deney grubundaki öğrencilerin uygulama öncesi, uygulama sonrası ve kalıcılık uygulamasında fene ilişkin tutum puanlarının anlamlı bir farklılık gösterdiği belirlenmiştir $\left(\mathrm{X}^{2}=17,498 ; \mathrm{p}<0,05\right)$. Farklılığın hangi uygulama sonucunda elde edilen tutum puanları arasında olduğunun belirlenmesi amaciyla Wilcoxon işaretler testi hesaplanmış ve hesaplama sonucunda deney grubundaki öğrencilerin tutum son tutum puanları ile kalıcılık tutum puanlarının benzerlik gösterdiği belirlenmiştir. Öğrencilerin uygulama sonrasında artan olumlu tutumlarının zamanla değişmediği, kalıcı olduğu tespit edilmiştir.

Tablo 4'te yer alan bilgiler incelendiğinde, kontrol grubundaki öğrencilerin uygulama öncesi, uygulama sonrası ve kalıcılık uygulamasında fene ilişkin tutum ölçeği puanlarının anlamlı bir değişiklik gösterdiği saptanmıştır $\left(X^{2}=10,892 ; \mathrm{p}<0,05\right)$. Wilcoxon işaretler testi hesaplaması sonucunda kontrol grubundaki öğrencilerin kalıcılık tutum puanlarının son test tutum puanlarından daha yüksek olduğu tespit edilmiştir. 
Öğrencilerin fene ilişkin tutumlarının uygulama öncesi, sonrası ve kalıcılık test puanlarının öğrencilerin cinsiyetlerine göre anlamlı bir farklılık gösterip göstermediğinin tespit edilmesi amaciyla hesaplanan betimsel istatistikler ve Mann Whitney U testi sonuçları Tablo 5 ve Tablo 6'da gösterilmiştir.

Tablo 5. Öğrencilerin Ön Test, Son Test ve Kalıcllık Testi Puanlarının Cinsiyetlerine Göre Betimsel İstatistikleri

\begin{tabular}{llccr}
\hline Uygulama zamanı & Cinsiyet & N & $\overline{\mathbf{X}}$ & SS \\
\hline Ön test & Kiz & 11 & 62,91 & 12,42 \\
& Erkek & 28 & 59,54 & 12,38 \\
\hline Son test & Kiz & 11 & 64,45 & 10,83 \\
& Erkek & 28 & 61,39 & 10,74 \\
\hline Kalıcilık testi & Kiz & 11 & 62,91 & 12,42 \\
& Erkek & 28 & 59,54 & 12,38 \\
\hline
\end{tabular}

Tablo 6'da yer alan bilgiler incelendiğinde öğrencilerin fene ilişkin tutum ön test puanlarının $(\mathrm{z}=0,203 ; \mathrm{p}>0,05)$, son test puanlarının $(\mathrm{z}=1,204 ; \mathrm{p}>0,05)$ ve kalıc1lik testi puanlarının $(\mathrm{z}=1,063 ; \mathrm{p}>0,05)$ öğrencilerin cinsiyetlerine göre anlamlı bir farklılık göstermediği belirlenmiştir.

Tablo 6. Öğrencilerin Ön Test, Son Test ve Kalıcılık Testi Puanlarının Cinsiyetlerine Göre Hesaplanan Mann Whitney U Testi Sonuçları

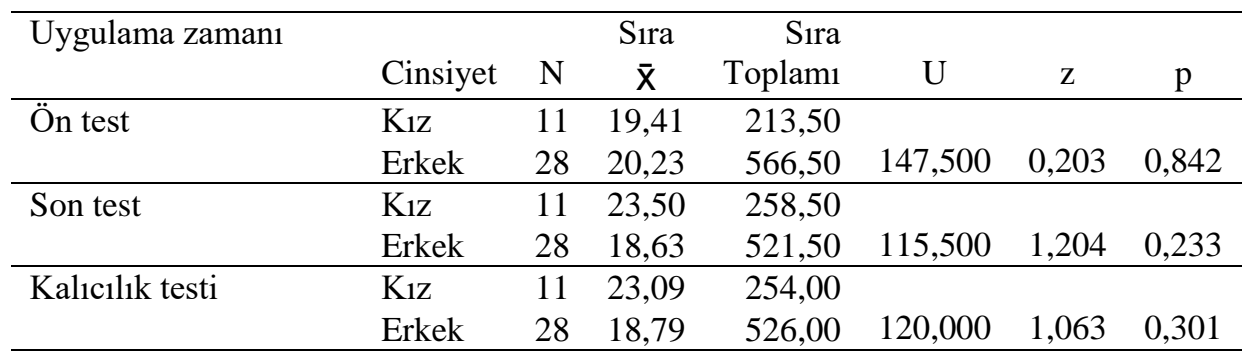

Öğrencilerin fene ilişkin tutumlarının uygulama öncesi, sonrası ve kalıc1lık test puanlarının öğrencilerin sınıf düzeylerine göre anlamlı bir farklılık gösterip göstermediğinin tespit edilmesi amacıyla hesaplanan betimsel istatistikler ve Mann Whitney U testi sonuçları Tablo 7 ve Tablo 8'de gösterilmiştir. 
Tablo 7. Öğrencilerin Ön Test, Son Test ve Kalıcılık Testi Puanlarının Sınıf Düzeylerine Göre Hesaplanan Betimsel İstatistikleri

\begin{tabular}{llccr}
\hline Uygulama zamanı & Sınıf düzeyi & N & $\overline{\mathbf{X}}$ & SS \\
\hline Ön test & 4. sinıf & 20 & 62,05 & 11,77 \\
& 5. sinıf & 19 & 58,84 & 13,00 \\
\hline Son test & 4. sinif & 20 & 63,70 & 9,75 \\
& 5. sinif & 19 & 60,74 & 11,71 \\
\hline Kalıcılık testi & 4. sinıf & 20 & 62,05 & 11,77 \\
& 5. sinıf & 19 & 58,84 & 13,00 \\
\hline
\end{tabular}

Tablo 8'de yer alan bilgiler incelendiğinde öğrencilerin fene ilişkin tutum ön test puanlarının $(\mathrm{z}=0,507 ; \mathrm{p}>0,05)$, son test puanlarının $(\mathrm{z}=0,830 ; \mathrm{p}>0,05)$ ve kalıcılık testi puanlarının $(\mathrm{z}=0,746 ; \mathrm{p}>0,05)$ öğrencilerin öğrenim gördükleri sınıf düzeyine göre anlamlı bir farklılık göstermediği belirlenmiştir. Diğer bir ifade ile ilköğretim 4 . ve 5 . sınıf düzeyindeki öğrencilerin uygulama öncesinde, sonrasında ve kalıcılık çalışmasındaki tutum düzeylerinin benzerlik gösterdiği tespit edilmiştir.

Tablo 8. Öğrencilerin Ön Test, Son Test ve Kalıcılık Testi Puanlarının Sınıf Düzeyine Göre Hesaplanan Mann Whitney U Testi Sonuçları

\begin{tabular}{llrrrrrr}
\hline Uygulama zamanı & $\begin{array}{l}\text { Sinıf } \\
\text { düzeyi }\end{array}$ & $\mathrm{N}$ & $\begin{array}{c}\text { Sira } \\
\overline{\mathrm{X}}\end{array}$ & $\begin{array}{r}\text { Sira } \\
\text { Toplamı }\end{array}$ & $\mathrm{U}$ & $\mathrm{z}$ & $\mathrm{p}$ \\
\hline Ön test & 4. sinıf & 20 & 19,10 & 382,00 & & & \\
& 5. sinıf & 19 & 20,95 & 398,00 & 172,000 & 0,507 & 0,627 \\
\hline Son test & 4. sinıf & 20 & 21,48 & 429,50 & & & \\
& 5. sinıf & 19 & 18,45 & 350,50 & 160,500 & 0,830 & 0,411 \\
\hline Kalıcılık testi & 4. sinıf & 20 & 21,33 & 426,50 & & & \\
& 5. sinıf & 19 & 18,61 & 353,50 & 163,500 & 0,746 & 0,461 \\
\hline
\end{tabular}

Öğrencilerin fene ilişkin tutumlarının uygulama öncesi, sonrası ve kalıcılık test puanlarının öğrencilerin görme düzeylerine göre anlamlı bir farklılık gösterip göstermediğinin tespit edilmesi amaciyla hesaplanan betimsel istatistikler ve Mann Whitney U testi sonuçları Tablo 9 ve Tablo 10' da gösterilmiştir. 
Tablo 9. Öğrencilerin Ön Test, Son Test ve Kalıcılık Testi Puanlarının Görme Düzeylerine Göre Hesaplanan Betimsel İstatistikleri

\begin{tabular}{llccr}
\hline Uygulama zaman1 & Görme düzeyi & N & $\overline{\mathbf{X}}$ & SS \\
\hline Ön test & Total kör & 26 & 50,00 & 13,06 \\
& Görme yetersizliği & 13 & 44,08 & 14,14 \\
\hline Son test & Total kör & 26 & 62,00 & 9,94 \\
& Görme yetersizliği & 13 & 62,77 & 12,53 \\
\hline Kalıcılık testi & Total kör & 26 & 61,00 & 12,20 \\
& Görme yetersizliği & 13 & 59,46 & 13,00 \\
\hline
\end{tabular}

Tablo 10'da yer alan bilgiler incelendiğinde öğrencilerin fene ilişkin tutum ön test puanlarının $(\mathrm{z}=1,298 ; \mathrm{p}>0,05)$, son test puanlarının $(\mathrm{z}=0,522 ; \mathrm{p}>0,05)$ ve kalıcılık testi puanlarının $(z=0,507 ; p>0,05)$ öğrencilerin görme düzeylerine göre anlamlı bir farklılık göstermediği saptanmıştır. Total kör ve az gören öğrencilerin uygulama öncesinde, sonrasında ve kalıcılık çalışmasında fene ilişkin tutum düzeylerinin benzerlik gösterdiği belirlenmiştir.

Tablo 10. Öğrencilerin Ön Test, Son Test ve Kalıcılık Testi Puanlarının Görme Düzeylerine Göre Hesaplanan Mann Whitney U Testi Sonuçları

\begin{tabular}{llrrrrrr}
\hline Uygulama & Görme düzeyi & \multicolumn{7}{c}{$\begin{array}{c}\text { Sira } \\
\text { zamanı }\end{array}$} & & $\mathrm{N}$ & $\begin{array}{c}\text { Sira } \\
\text { Toplamı }\end{array}$ & $\mathrm{U}$ & $\mathrm{z}$ & $\mathrm{p}$ \\
\hline Ön test & Total kör & 26 & 21,67 & 563,50 & & & \\
& Az gören & 13 & 16,65 & 216,50 & 125,500 & 1,298 & 0,198 \\
\hline \multirow{2}{*}{ Son test } & Total kör & 26 & 19,33 & 502,50 & & & \\
& Az gören & 13 & 21,35 & 277,50 & 151,500 & 0,522 & 0,607 \\
\hline \multirow{2}{*}{ Kalıcıllk testi } & Total kör & 26 & 20,65 & 537,00 & & & \\
& Az gören & 13 & 18,69 & 243,00 & 152,000 & 0,507 & 0,627 \\
\hline
\end{tabular}

\section{TARTIŞMA ve SONUÇ}

Araştırma kapsamında deney grubundaki öğrencilerle kontrol grubundaki öğrencilerin fene ilişkin tutum düzeyleri arasında deney grubu lehine anlamlı bir farklılığın olduğu sonucuna ulaşılmıştır. Öğrencilerin fene ilişkin tutumları ile ilgili sonuçlar genel olarak değerlendirildiğinde, araştırmaya dayalı öğrenme yaklaşımı ile gerçekleştirilen derslerin sadece öğretmen merkezli derslere göre görme yetersizliği olan öğrencilerde daha fazla olumlu tutumlar geliştirdiği sonucuna varılmıştır. Ayrıca araştırmada deney grubunun 
da kontrol grubunun da ön test, son test ve kalıcılık testlerinden aldıkları tutum puanlarında artış olmakla beraber deney grubunun puan ortalamaları kontrol grubuna göre daha yüksektir. Bu bulgu, araştırmaya dayalı öğrenme yaklaşımının öğrencilerin derse yönelik tutumları üzerinde etkili olduğunu ortaya koyan birçok çalışmayı desteklemektedir (örn., Akpullukçu, 2011; Koç ve Böyük, 2012; Lord ve Orkwiszewski, 2006; Sakar, 2010; Tatar, 2006). Aynı zamanda tutumlarla ilgili çalışmalarda, bilimsel süreç becerilerinin öğretildiği öğrencilerin fene ilişkin ilgi ve tutumlarının daha olumlu olduğunu (Doğruöz, 1998), bununla birlikte öğretmenlerin bilimsel bilgi edinme yollarına ilişkin ilgilerinin ve bilimsel araştırma yapmaya karşı tutumlarının olumlu yönde gelişmiş olması öğrencilerin de derse olan ilgi ve başarılarını artırdığını ortaya koymaktadır (Marlow ve Ellen 1999). Bu bağlamda gerçekleştirilen çalışmalar araştırma sonuçlarını desteklemektedir. Ayrıca, Kaya ve Böyük (2011), tarafından yapılan çalışmada, öğrencilerin, fen deneylerine yönelik ortalama tutum puanlarının, Fen ve Teknoloji dersine yönelik ortalama tutum puanlarından daha yüksek olduğu bulunmuştur. Ayrıca Koç ve Böyük (2012) tarafından gerçekleştirilen çalışmada, basit malzemelerle yapılan fen deneylerinin grubun tutumları açısından anlamlı bir farklılığ ortaya koyduğu belirlenmiştir. Yapılan çalışma görme yetersizliği olan öğrencilerle yapılan araştırmayı destekleyici niteliktedir. Bu çerçevede, görme yetersizliği olan öğrencilerin gözlemde bulunma, tahmin yapma, deneyi gerçekleştirme, ölçüm yapma, verileri yorumlama, sonuç çıkarma gibi bilimsel işlem becerilerini kullanmaları aynı zamanda araştırma kaynaklarını (internet, kütüphane, ders materyalleri vd.) kullanarak araştırmalar yapmaları ve sürece katılarak yaparak yaşayarak öğrendikleri zaman fen bilimleri dersini daha zevkli bir ders olarak görmekte oldukları, derse ait olumlu tutumlar gerçekleştirdikleri düşünülmektedir. Diğer bir deyişle görme yetersizliği olan öğrencilerin deney dersi için hazırlık yapma, deneyi planlama boyutunda araştırmalar yapmaları nedensel bir ilişki olarak ilgi oluşturmalarına, deneyi gerçekleştirme sürecinde dokunsal ve işitsel uyaranlar vasıtasıyla etkileşimde bulunmaları ise sunuya dayalı fen bilimleri derslerine göre daha fazla olumlu tutumlar geliştirmelerini sağlamaktadır. 
Araştırma kapsamında deney grubunda yer alan öğrencilerle kontrol grubunda yer alan öğrencilerin tutumlarına ilişkin; ön test puan ortalamalarında anlamlı bir farklılığın olmadığı, ortalama puanlarının benzer olduğu belirlenmiştir. Araştırmada birbirine benzer gruplar seçildiği için, ön test puanları arasında farklılığın olmadığı düşünülmektedir.

Çakır vd. (2007) çalışmalarında, ilköğretim II. kademe öğrencilerinin fen bilimleri dersine yönelik tutumlarını belirlemeyi amaçlamışlardır. Araştırmacılar yapılan çalışma sonuçlarına göre, öğrencilerin Fen Bilgisi dersin adı fen bilimleri ise metnin tamamında bu şekilde ifade edilmeli farklılık olmamalı dersine yönelik tutumları ile onların sınıf düzeyleri, kendilerine ait bir çalışma ortamının olması, Fen Bilgisi dersindeki başarı durumu ve laboratuvar kullanma sıklığı arasında anlamlı bir ilişkinin bulunduğunu fakat cinsiyetleri, yaşadıkları yerleşim birimi, ailelerinin eğitim durumu ve ailenin sosyoekonomik durumu arasında anlamlı bir farkın olmadığını ifade etmiş̧lerdir. Kaya ve Böyük (2011), öğrencilerin Fen ve Teknoloji derslerine ve fen deneylerine ilişkin toplam ortalama tutum puanının cinsiyet, sınıf düzeyi ve yaş değişkenleri göre farklılık gösterip göstermediğini incelenmiştir. Yapılan çalışma sonuçlarına bağlı olarak; cinsiyete göre anlamlı bir farklılı̆̆ın oluşmadığı görülmüştür. Can ve Dikmentepe (2015), çalışmalarında Fen ve Teknoloji dersine yönelik olarak öğrencilerin cinsiyet açısından tutumlarında anlamlı bir farlılığın olmadığını, Gülden ve Timur (2016) çalışmalarında 5. sınıf öğrencilerinin fene ilişkin cinsiyet açısından öğrencilerin tutumlarında farklılaşmanın olmadığını belirlemiştir. Uyanık (2017) tarafından gerçekleştirilen çalışmada ise fen dersine yönelik tutum ölçek puanlamalarında kız öğrencilerin lehine düşük düzeyde bir farklılığın olduğu belirlenmiştir. Koç ve Böyük (2012) fen deneylerinin grubun tutumu açısından kız ve erkek öğrenciler için ayrı ayrı da incelemiş, yapılan analizler sonucunda cinsiyete göre anlamlı bir farlılığın elde edilmediğini tespit etmişlerdir. Aynı zamanda benzer yetersizlik grubuna yönelik olması nedeniyle önem taşıyan bir çalışma Atalay (2019) tarafından gerçekleştirilmiştir. Bu çalışmada görme yetersizliği olan 5. sınıf öğrencilerinin fen bilimleri dersine yönelik olarak cinsiyet açısından anlamlı bir farklılığın olmadığı tespit edilmiştir. 
Gerçekleştirilen çalışmalarla yapılan bu araştırmanın cinsiyet açısından benzer sonuçlarının olduğu görülmektedir. Ayrıca Kaya ve Böyük (2011), tarafından gerçekleştirilen çalışmanın diğer sonuçlarına göre, öğrencilerin fene ilişkin ve fen deneylerine yönelik tutum puanları arasında; sınıf düzeyine bağlı olarak öğrencilerin, tutum puanlarında 8. sınıfta okuyan öğrencilerin lehine anlamlı farklılaşma olduğu görülmüştür. Yaş farklılığına göre öğrencilerin, tutum puanlarının anlamlı bir farklılaşma oluşturduğu tespit edilmiştir. Ancak, Erden (2007)'in yaptığı çalışmadan elde edilen bulgulara sonucunda, öğrencilerin okudukları sınıfa göre fene ilişkin tutumları arasında önemli bir farkın bulunmadığını belirtmiştir. Araştırmada, görme yetersizliği olan 4 ve 5 . Sinıfta okuyan öğrencilerin tutumları arasında farkın olmamasını, fen bilimleri dersi müfredat programının her iki sınıfta da hemen hemen aynı konuları kapsıyor olmasından kaynaklandığını bu sebeple öğrencilerin 4. sınıftan 5 . sınıfa geçtiklerinde fene ilişkin tutumlarını değiştirici zorluklarla karşılaşmamaları olduğunu ifade etmiştir. Yapılan çalışma kapsamında 4 ve 5. sınıf ortak konularından deneyler oluşturulmuştur ve uygulanmıştır. Bu sonuç Erden (2007)'in yaptığı araştırma ile örtüşmektedir. Aynı zamanda gerçekleştirilen araştırmada görme yetersizliği olan öğrencilerin sınıf düzeylerinin birbirine çok yakın olması (4. ve 5. sınıf) ve görme düzeyleri gibi değişkenler incelendiğinde, öğrencilerin, sınıf düzeylerine ve görme düzeylerine göre anlamlı bir farklılığın bulunmadığı belirlenmiştir.

Araştırmanın sonuçları değerlendirildiğinde, görme yetersizliği olan öğrencilerin araştırmaya dayalı öğrenme yaklaşımına göre deneysel işlem becerilerini kazanmaları, fen bilimleri dersine olan ilgi ve tutumlarını artırdığı söylenebilir. Deney grubunda yer alan öğrencilerin izleme test puanlarının son test puanlarına göre azalmadığı görülürken, kontrol grubunda yer alan öğrencilerin izleme test puanlarında bir düşüşün olduğu görülmüştür. $\mathrm{Bu}$ bağlamda görme yetersizliği olan öğrencilerin araştırmaya dayalı öğrenme yaklaşımı modellerinden rehberli keşfetme modeli ile yapılan çalışmanın öğrencilerin tutumlarını olumlu yönde etkilediği tespit edilmiştir.

Görme yetersizliği olan öğrencilerin fene ilişkin olumlu tutumlar geliştirebilmeleri için öğretmenlerin derslerinde araştırma becerilerine yönelik olarak deney, gözlem ve 
demonstrasyon gibi etkinlikleri kullanmaları önerilebilir. Görme engeliler okullarında ve diğer eğitim ortamlarında öğrencilerin araştırma yapacakları, deneyleri uygulayabilecekleri kaynakların ve ortamların zenginleştirilmesi öğrencilerin daha fazla uygulamalar yapabilmelerinde motivasyon kaynağı olacaktır. Bu durum ise görme yetersizliği olan öğrencilerin fene ilişkin olumlu tutum geliştirmelerine hizmet edebilir. Ayrıca araştırmaya dayalı öğrenme yaklaşımı ile yapılan dersler sonucunda öğrencilerin araştırma becerilerini genelleyebilmeleri, öğrencilerin günlük yaşamlarında araştırma becerilerini kullanabilmeleri açısından da katma değer sağlayabilir. Ulusal ve uluslararası yayınlar incelendiğginde, görme yetersizliği olan öğrencilerle ilgili yapılan çalışmaların daha ziyade ortaokul ve lise düzeyinde yapıldığı, okul öncesi ve ilkokul düzeyinde yapılan yayın sayısının sınırlı olduğu görülmektedir. Yapılacak çalışmalarda görme yetersizliği olan öğrencilerin okul öncesi ve ilkokul gibi eğitim ortamlarına 1şık tutacak çalışmalara daha fazla odaklanılmasının bilhassa Türkiye'de büyük bir boşluğu dolduracağı düşünülmektedir. Araştırma kapsamında yapılan çalışma görme engelliler okulunda gerçekleştirilmiştir. Kaynaştırma eğitim ortamlarında bulunan az gören ya da total kör öğrenciler için de benzer çalışmalar uygulanabilir. Bu tür çalışmalarda görme yetersizliği olan öğrencinin grup içerisinde ekip çalışmalarına katılabilmesi, iletişim araçlarını kullanabilmesi, görme yetersizliği olan öğrencilerin hem akademik başarısını hem de sosyal kabulünü destekleyeceği bilinmelidir. Yapılan bu araştırmada görme yetersizliği olan öğrencilerin, cinsiyet, sınıf ve görme düzeyi değişkenleri ele alınmıştır. İleri araştırmalarda bu değişkenlere ek olarak akademik başarı, öz yeterlik, motivasyon gibi farklı değişkenler ve bu değişkenlerin birbiri ile ilişki boyutları incelenebilir. 


\section{KAYNAKLAR}

Akpullukçu, S. (2011). Fen ve teknoloji dersinde araştırmaya dayalı öğrenme ortamının öğrencilerin akademik başarı hatırda tutma düzeyi ve tutumlarına etkisi. Yüksek Lisans Tezi, Dokuz Eylül Üniversitesi Eğitim Bilimleri Enstitüsü, İzmir.

Akpullukçu, S., \& Günay, Y. (2013). Fen ve teknoloji dersinde araştırmaya dayalı öğrenme ortamının öğrencilerin akademik başarı hatırda tutma düzeyi ve tutumlarina etkisi. Ege Ĕ̈itim Dergisi, 14(1), 67-89.

Aslan, C., \& Savaş, M. A. (2020). Görme yetersizliği olan öğrenciler için zeka oyunlarıyla fen eğitimi. Y. Çıkıllı \& İ. Yüksel (Ed.), Özel eğitim gereksinimi olan ögrenciler için zeka oyunlarlyla fen eğitimi ve etkinlik örnekleri içinde (s. 107-136). Ankara: Nobel.

Atalay, S. (2019). Görme engelli 5. sinıf ögrencilerinin Fen dersine yönelik tutum, öz yeterlik ve motivasyonlarının incelenmesi. Yüksek Lisans Tezi, Balıkesir Üniversitesi Fen Bilimler Enstitüsü, Balıkesir.

Belhan, Ö. (2012). Bilim fen teknoloji kulübünün ögrencilerin fen ve teknoloji okur yazarliğl ve fene yönelik tutumlarına etkisi Yüksel lisans tezi, Sakarya Üniversitesi, Eğitim Bilimleri Enstitüsü, Sakarya.

Büyüköztürk, Ş., Çakmak, E. K., Akgün, Ö. E., Karadeniz, Ş., \& Demirel, F. (2012). Bilimsel araştırma yöntemleri. Ankara: Pegem.

Campbell, D. T., \& Stanley, J. G. (1996). Experimental and quasi-experimental. Design for research. Ran McNally, Chicago, III.

Can, Ş., \& Dikmentepe, E. (2015). Ortaokul öğrencilerinin fen ve teknoloji dersi ile fen deneylerine yönelik tutumlarının araştırılması (Muğla ili örneği). Muğla Sitkı Koçman Üniversitesi Ĕ̈itim Fakültesi Dergisi, 2(1), 44-58.

Carin, A. A., Bass, J. E., \& Contant, T. L. (2005). Teaching science as inquiry. New Jersey: Prentice Hall.

Çakır, N. K., Şenler, B., \& Taşkın, B. G. (2007). İlköğretim 2. kademe öğrencilerinin fen bilgisi dersine yönelik tutumlarinin belirlenmesi. Türk Ĕgitim Bilimleri Dergisi, 5(4), 637-655.

Doğruöz, P. (1998). Effect of science process skill oriente lesson on understanding of fluid force concepts. Yüksek Lisans Tezi, Orta Doğu Teknik Üniversitesi Fen Bilimleri Esntitüsü, Ankara.

Erden, E. (2007). Sınıf öğretmenlerinin fen öğretimi öz yeterlilik inançlarının ögrencilerin fen tutumları ve akademik başarıları üzerindeki etkisi. Yüksek Lisans Tezi, Ege Üniversitesi Sosyal Bilimler Esntitüsü, İzmir. 
Fraenkel, J. R., \& Wallen, N. E. (2009). How to design and evaluate research in education (Vol. 7). New York: McGraw-Hill.

Geban, Ö., Ertepınar, H., Yılmaz, G., Altın, A., \& Şahbaz, F. (1994, Eylül). Bilgisayar destekli ĕgitimin ögrencilerin fen bilgisi başarllarına ve fen bilgisi ilgilerine etkisi. I. Ulusal Fen Bilimleri Eğitimi Sempozyumu'nda sunulmuş bildiri, İzmir.

Güden, C., \& Timur, B. (2016). Ortaokul öğrencilerinin fen bilimlerine yönelik tutumlarının bazı değişkenlere göre incelenmesi (Çanakkale örneği). International Journal of Active Learning, 1(1), 49-72.

Güzel-Özmen, R., \& Karakoç, T. (2020). Fen bilgisi öğretimi. H. İ. Diken (Ed.), Illkögretimde kaynaştırma içinde (s. 519-556). Ankara: Pegem.

Kağıtçıbaşı, Ç. (1988). Tutum değişimine kuramsal yaklaşımlar. İstanbul: İnsan ve İnsanlar.

Kahyaoğlu, M., \& Yangın, S. (2007). İlköğretim öğretmen adaylarının mesleki öz yeterliklerine ilişkin görüşleri. Kastamonu Ĕ̆itim Dergisi, 15(1), 73-84.

Karakaya, İ. (2009). Bilimsel araştırma yöntemleri. A. Tanrıöğen (Ed.), Bilimsel araştırma yöntemleri içinde (s. 57-83). Ankara: Anı.

Karakoç, T. (2016). Görme yetersizliği olan öğrencilerin araştırmaya dayalı ögrenme yaklaşımı modellerinden rehberli keşfetme modelinin deneysel işlem becerilerine, akademik başarllarına ve fen bilimleri dersine yönelik tutumlarına etkisi. Doktora Tezi, Gazi Üniversitesi Eğitim Bilimleri Esntitüsü, Ankara.

Kaya, H., \& Böyük, U. (2011). İlköğretim II. kademe öğrencilerinin fen ve teknoloji derslerine ve fen deneylerine karşı tutumları. TÜBAV Bilim Dergisi, 4(2), 120130.

Kızılaslan, A., \& Sözbilir, M. (2017). Görme yetersizliği olan öğrenciler için tasarlanan etkinliğin bilimsel süreç becerilerine göre analizi. SDU International Journal of Education Studies, 4 (2), 86-95.

Koç, A., \& Böyük, U. (2012). Basit malzemelerle yapılan deneylerin fene yönelik tutuma etkisi. Türk Fen Ë̆itim Dergisi, 9 (4), 102-118.

Lord, T., \& Orkwiszewski, T. (2006). Moving from didactic to inquiry-based instruction in a science laboratory. The American Biology Teacher, 68(6), 342-345.

Milli Eğitim Bakanlığı (2013). Ilköğretim kurumları (ilkokullar ve ortaokullar) fen bilimleri dersi (3, 4, 5, 6, 7 ve 8. Sinıflar) ögretim programı. Ankara.

Marlow, M. P., \& Ellen, S. (1999, March). Science teachers attitudes about inquirybased science. Paper presented at The Annual Meeting of The National Association for Research in Science Teaching, Boston.

Mastropieri, M. A., \& Scruggs, T. E. (1995). Teaching science to students with disabilities in general education settings. Teaching Exceptional Children, 
27(4), 10-13.

Organisation for Economic Cooperation and Development (OECD) (2007). PISA 2006

Science Competencies for Tomorrow's World [online]. (23 April 2019), http://www.pisa.oecd.org.

Okçu, B., Yazıcı, F., \& Sözbilir, M. (2016). Ortaokul düzeyindeki görme yetersizliği olan öğrencilerin okuldaki öğrenim sürecine dair görüşleri. Amasya Üniversitesi Ĕ̈itim Fakültesi Dergisi, 5(1), 51-83.

Patton, J. R. (1995). Teaching science to students with special needs. Teaching Exceptional Children, 27(4), 4-6.

Sakar, Ç. (2010). Araştırmaya dayalı kimya öğretiminin öğrencilerin akademik başarı ve tutumları üzerine etkisi. Yüksek Lisans Tezi, Selçuk Üniversitesi Eğitim Bilimleri Enstitüsü, Konya.

Saracaloğlu, A., Kesercioğlu, T., Gökler, J., \& Serin, O. (2001, Haziran). İlköğretim okulu ögretmenlerinin ögretmenlik mesleğine yönelik tutumlarının bazı değişkenler açısından karşılaştırılması. X. Ulusal Eğitim Bilimleri Kongresi'nde sunulmuş bildiri, Bolu.

Schibeci, R. A. (1983). Selecting appropriate attitudinal objectives for school science. Science Education, 67(5), 595-603.

Sözbilir, M., Zorluoğlu, S. L., Okçu, B., Kızılaslan, A., Gül, Ş., Bülbül, M., \& Yazıcı, F. (2017). Görme yetersizliği olan bireylere fen öğretimi. M. Ergun (Ed.), Fen bilimleri ögretiminde yeni yaklaşımlar İçinde (s. 35-66). Ankara: Nobel.

Uyanık, G. (2017). İlkokul öğrencilerinin fen bilimleri dersine yönelik tutumları ile akademik başarıları arasındaki ilişki. Türk Bilim Araştırma Vakfi, 10 (1), 8693.

Tatar, N. (2006). Illköğretim fen eğitiminde araştırmaya dayalı öğrenme yaklaşımının bilimsel süreç becerilerine, akademik başarıya ve tutuma etkisi. Doktora Tezi, Gazi Üniversitesi Eğitim Bilimleri Enstitüsü, Ankara.

Tekin-İftar, E., \& Kırcaali-İftar, G. (2006). Özel eğitimde yanlışsız öğretim yöntemleri. Ankara: Nobel.

Yazıcı, F. (2017). 6. sınıf görme engelli ögrencilere "vücudumuzdaki sistemler" ünitesinde yer alan kavramların ögretimi. Doktora tezi, Atatürk Üniversitesi, Eğitim Bilimleri Enstitüsü, Erzurum.

Yıldırım, A., \& Şimşek, H. (2016). Sosyal bilimlerde nitel araştirma yöntemleri. Ankara: Seçkin.

Yılmaz, T., \& Çavuş, M. (2021). Probleme dayalı öğrenmenin 5. sınıf öğrencilerinin fen bilimleri dersi akademik başarılarına ve tutumlarına etkisi. Bilim, Ĕgitim, Sanat ve Teknoloji Dergisi, 5(1), 1-24.

Yüksel, İ., \& Aslan, C. (2020). Özel eğitim, zeka oyunları ve fen eğitiminde temel kavramlar. Y. Çıkıllı \& İ. Yüksel (Ed.), Özel eğitim gereksinimi olan 
öğrenciler için zeka oyunlarıyla fen ĕgitimi ve etkinlik örnekleri içinde (s. 116). Ankara: Nobel.

\section{ORCID}

Ayşegül ATAMAN iD https://orcid.org/0000-0002-5566-6606 


\section{SUMMARY}

\section{Introduction}

Recently, the inquiry based approaches maintained in the teaching of science classes and the students with visual impairment have similar qualities. Students with visual impairment develop natural habits about situations such as discovering, discovering by testing, questioning, discovering concrete objects when they effectively use their sense organs during the learning activity. It is assumed that the maintenance of such kinds of approaches to the teaching of sciences will activate the interests of students with visual impairment at a higher level, will contribute to their understanding and provide them with more opportunities in the future. Such considerations have foregrounded the inquiry based learning approach for the students with visual impairment to develop more effective learning activities in their learning processes.

\section{Purpose}

The aim of the research study is to understand whether there is significant difference between the Guided discovery model, one of the inquiry based learning approach models to the teaching science to 4th and 5th grade primary students and the contribution of a traditional teaching to the attitudes towards science lessons for the students with visual impairment.

\section{Method}

The quasi-experimental design, which is among the experimental research designs, which is among the multi-subject designs, was used in the study. The population of the study is a primary school for the visually impaired in Ankara, Altındağ district, and the sample consists of 39 students in the experimental group $(N=20)$ and the control group $(N=19)$. The shared experiment and control groups were taken from both grades. The first group was named as the experiment group and the common units such as friction, erosion and dissolution were studied through inquiry approach as the science lessons of the 4 th and 5 th grades. The students in the control group learned the same units according to the traditional approach. In the research, "The Sciences Attitude Scale" was used by Geban, Ertepınar, Yılmaz, Altın and Şahbaz (1994) in order to test the attitudes of students with visual impairment to the sciences lessons. At the beginning of the research, the sciences attitude scale were applied as a pre-test to the students with visual impairment in the experiment and control groups. Following the application of data collection instruments, the units "friction, erosion and dissolution" were taught to both of the groups. After a 6 week instruction, the students with visual impairment in both groups took the pure sciences attitude scale as a post-test. Concerning the level the students with visual impairment reached in the units of science lessons, all the data collection instruments were reapplied to the students with visual impairment as a follow-up test 4 weeks after the post test in order to determine permanence. In the research, the qualitative findings gained from the tests were analyzed.

\section{Results}

According to the findings, the attitudes toward science lessons of the students with visual impairment in the experiment group in which the inquiry based approach was applied, were significantly different from those of the ones in the control group. No significant difference was found between the students in the experiment group in reference to their genders, class levels, and 
visual levels. In conclusion, it can be said that the inquiry based instruction approach has been more effective with students with visual impairment in developing their science attitudes when compared to the ones in traditional approaches. When the results of the research are evaluated, in summary; It can be said that students with visual impairment acquire experimental processing skills according to the inquiry based learning approach, increasing their interest and attitudes towards the science course. 
Ek 1: Etik Kurul Onay Sayfası

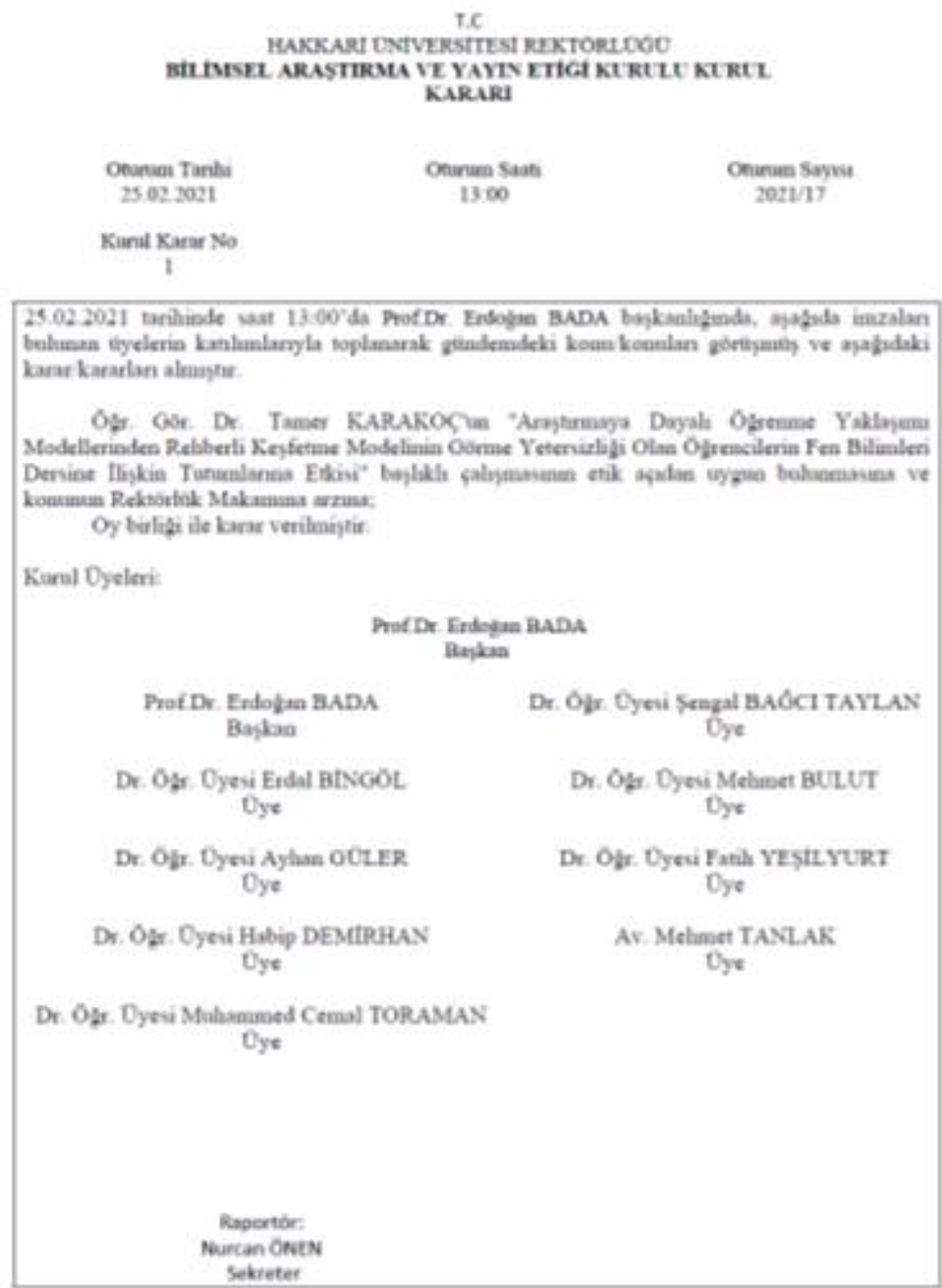

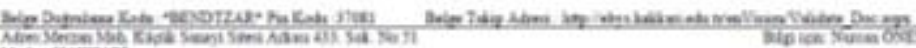

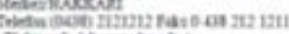

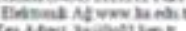


